\title{
Gebyrkortlagning i Århus Syd - geologisk, kemisk og hydrologisk datasammenstilling
}

Af Birgitte Hansen, Birthe Eg Jordt og Richard Thomsen (Grundvandsafdelingen, Natur og Miljø, Arhus Amt) samt Jette Sørensen (tidl. Sedimentsamarbejdet, nu Rambøll), Christian Kronborg og Ole Bjørslev Nielsen (Geologisk Institut, Aarhus Universitet)

Århus Syd-området er et ca. 150 $\mathrm{km}^{2}$ stort område sydvest for Århus i Århus Amt, som er blevet kortlagt i perioden fra 2003 til 2006 (Århus Amt, 2006). Formålet med kortlægningen er at vurdere den fysiske og kemiske tilstand af grundvandsmagasinerne samt den naturlige beskyttelse, sådan at der senere kan udarbejdes indsatsplaner for beskyttelse af grundvandet. Der er i den forbindelse udført forskellige undersøgelser i området.

Begravede dale og grundvandsforekomster Der er identificeret en række begravede dalstrukturer i undergrunden i Århus Sydområdet, hvor grundvandsforekomsterne findes (figuren nedenfor). Det er først og fremmest de geofysiske TEM-målinger, som har afsløret udbredelsen og forløbet af de begravede dale.

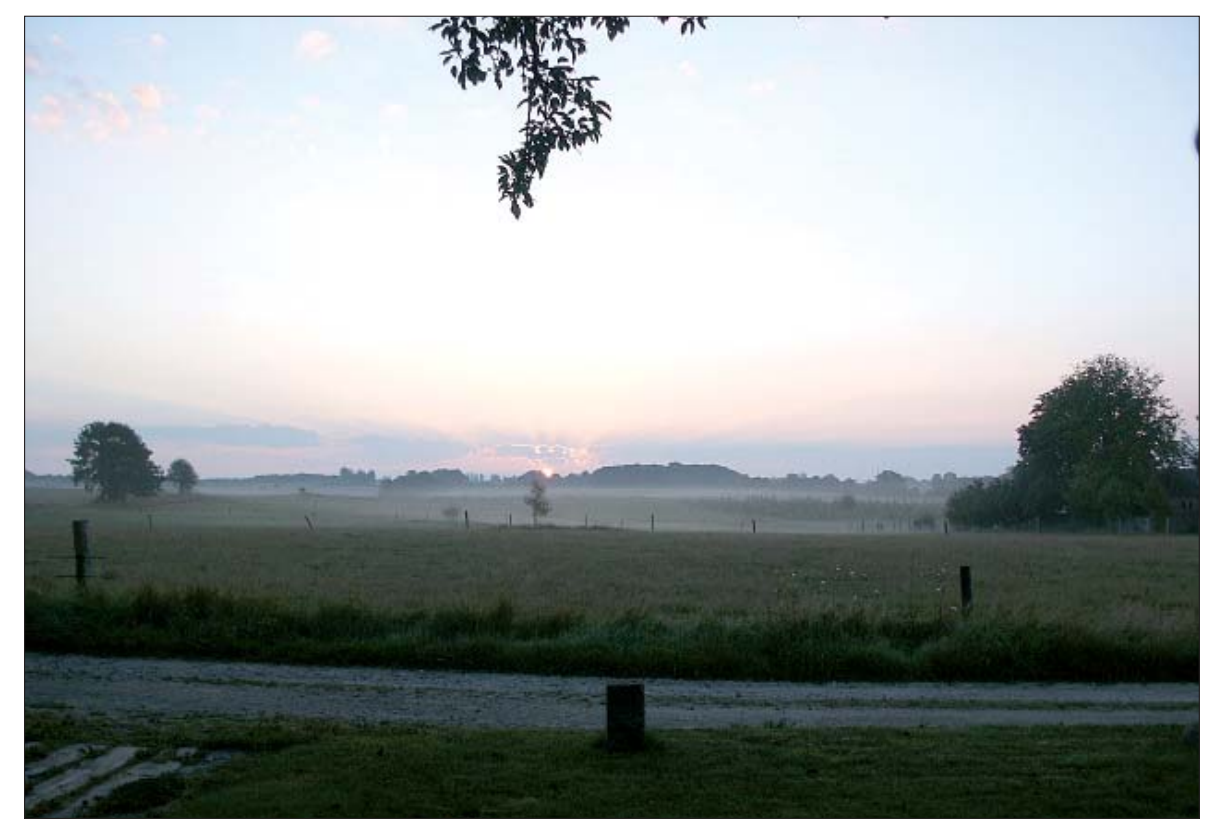

Landskabet ved Beder. (Foto: Richard Thomsen)

Geofysiske, geologiske og kemiske data Foruden TEM-sonderinger er der også udført geoelektriske målinger (PACEP og PACES) til estimering af tykkelsen af lerdæklagene over grundvandsmagasinet som led i vurderingen af nitratsårbarheden af grundvandsmagasinerne. Der er anvendt geologiske og kemiske informationer fra hovedparten af de boringer, som er udført i tidens løb i området. Der er også opstillet en geologisk model og en MIKE SHE-grundvandsmodel for området, som beskriver vandstrømningen $\mathrm{i}$ grundvandsmagasinerne.

Nye boringer og analysemetoder Som et vigtigt punkt i den gebyrfinansie-

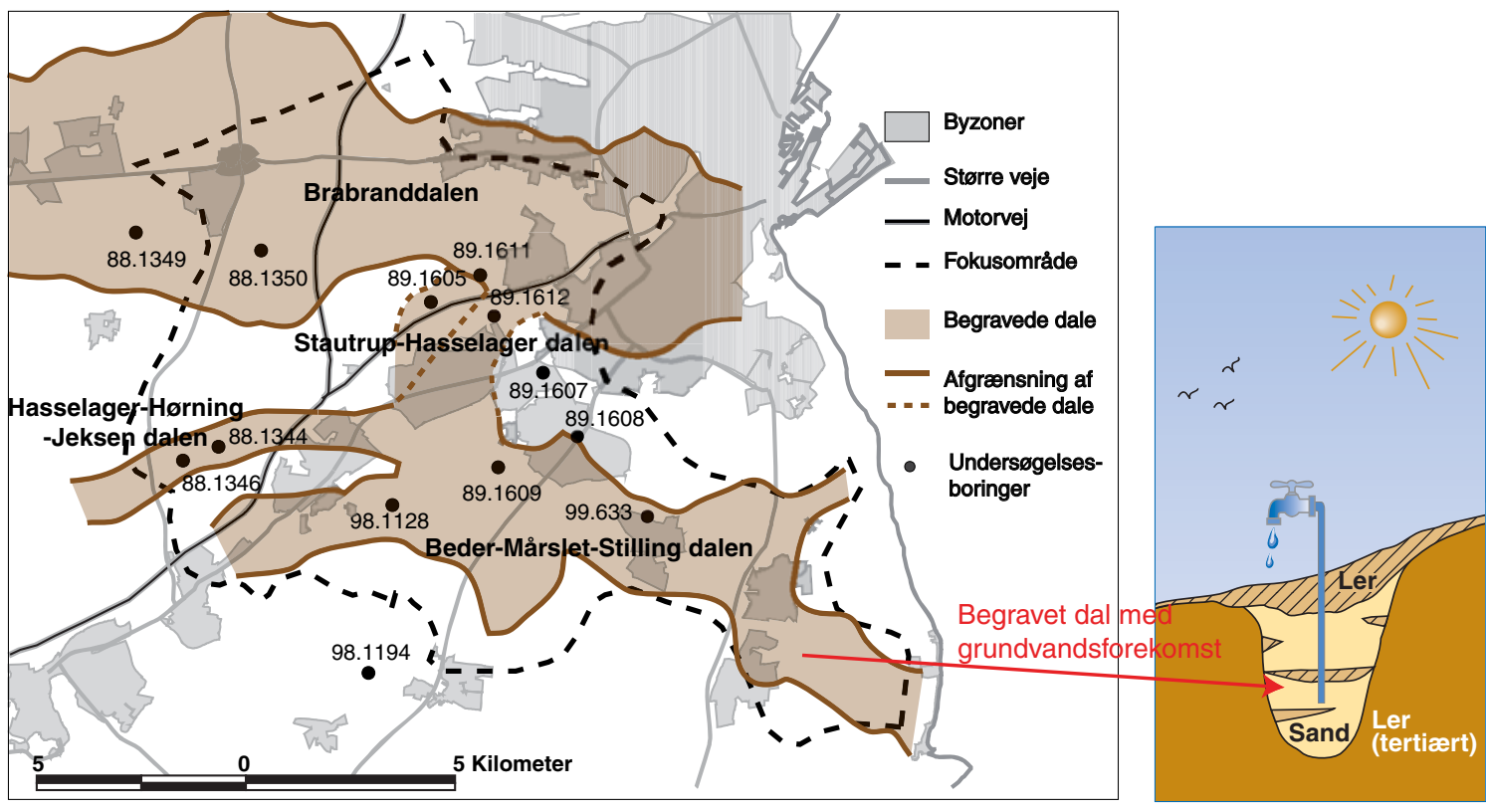

Oversigt over undersøgelsesboringer og begravede dale med grundvandsforekomster i Århus Syd-området.(Grafik: Forfatterne) 
rede kortlægning er der udført 15 nye dybe undersøgelsesboringer i området (ses på figuren nederst på foregående side). De er udført som lufthæveboringer, og samtidig med borearbejdet er jordprøverne blevet beskrevet. Efterfølgende er grundvandsspejlet pejlet, og der er udtaget vand- og sedimentprøver fra forskellige geologiske lag. Vandprøverne er analyseret for hovedbestanddele og udvalgte sporstoffer og pesticider. Pyritindholdet i sedimentet er bestemt som led i bestemmelse af nitratreduktionskapaciteten.

Desuden er indholdet af arsen bundet til pyrit i sedimentet også bestemt. Der er endvidere foretaget borehulslogging såsom naturlig gammalog, resistivitetslog, fluidresistivitetslog og induktionslog. Geologien i de nye undersøgelsesboringer er undersøgt i detaljer af Sedimentsamarbejdet på Geologisk Institut (SESAM) ved petrografiske og mineralogiske analyser, kornstørrelsesanalyser og prøvebeskrivelser.

\section{Vigtige resultater fra SESAM}

SESAMs resultater fra de nye undersøgelsesboringer er i høj grad brugt til at understøtte og tolke de øvrige geologiske og vandkemiske data fra boringerne.

Resultaterne fra de nye undersøgelsesboringer er desuden brugt til at generalisere resultater til regional skala i vurderingen af den fysiske udstrækning og kemiske tilstand af grundvandsmagasinerne. I den forbindelse har opdelingen og korrelationen af de forskellige geologiske lagserier, som er udført af SESAM, været uundværlige.

To af de begravede dale, som ses på figuren nederst på foregående side, nemlig Hasselager-Hørning-Jeksendalen og Brabranddalen, vil blive brugt til at illustrere, hvordan data er blevet syntetiseret, og grundvandsmagasinernes geologiske og kemiske tilstand er tolket.

Geologisk tolkning og forståelse På figuren nedenfor ses et geologisk pro-

\section{Den ustabile fingrusfraktion}

\section{Resultater fra SESAM}

I forbindelse med fingrusanalysen, som udføres af SESAM, tælles bl.a. antallet af kalkkorn i den ustabile fraktion. Kalkindholdet i den ustabile fingrusfraktion inddeles i 3 forskellige typer; kalk fra Kridt og Danien, palæozoisk kalk og kalkholdige sedimentære bjergarter, som på illustrationer tildeles farverne grøn, grå og brun (se figuren i boksen).

Generelt afhænger indholdet af mineraler i fingrusfraktionen af det underlag, som isen har bevæget sig hen over (Kronborg et al. 1990). Den oprindelige fordeling af kalkindholdet forudsættes derfor at være ens $i$ både smeltevandsaflejringer $o g$ moræneaflejringer, som er afsat af

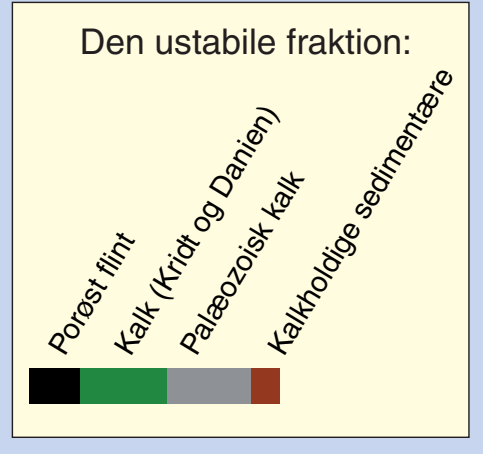

det samme isfremstød. Det vil sige, at udvaskningen af kalk $\mathrm{i}$ et sandet grundvandsmagasin, kan vurderes ved sammenligning med det intakte kalkindhold i den overliggende eller underliggende moræne. filsnit gennem den begravede HasselagerHørning-Jeksendalen, der blev kortlagt med TEM-målinger i 2003. På baggrund af de analyser, SESAM har udført, har det været muligt at korrelere de kvartære aflejringer af forskellige aldre mellem de to undersøgelsesboringer, der er placeret i HasselagerHørning-Jeksendalen.

Tilsvarende har det på baggrund af SESAM-analyserne været muligt at korrelere aflejringer i boringerne flere andre steder $\mathrm{i}$ Århus Syd-undersøgelsesområdet.

I hele området er kendskabet til opbygningen af de kvartære grundvandsmagasiner og for så vidt den generelle geologiske udvikling i området hermed blevet bedre belyst. I de begravede dale med grundvandsforekomster har SESAM-analyserne vist, at der findes aflejringer, der kan henføres til flere forskellige istider. I Hasselager-Hør-
ning-Jeksendalen findes der således sandede og lerede aflejringer fra både Elster-, Saaleog Weichsel-nedisningerne.

Denne viden om aflejringernes forskellige aldre er anvendt til at vise, at dalene i området kan være dannet på forskellige tidspunkter i løbet af Kvartærtiden. Det har blandt andet medført, at der under opstillingen af grundvandsmodellen er arbejdet med en dalspecifik zonering af den hydrauliske ledningsevne. Resultaterne af analyserne er ligeledes anvendt i forbindelse med tolkningen af vandkemien, for eksempel kan det kloridholdige vand, der ses i flere boringer i området, stamme fra marine aflejringer fra mellemistiderne, hvor klimaet har været varmere.

\section{Magasin med stor nitratsårbarhed}

I den begravede Hasselager-Hørning-Jeks-

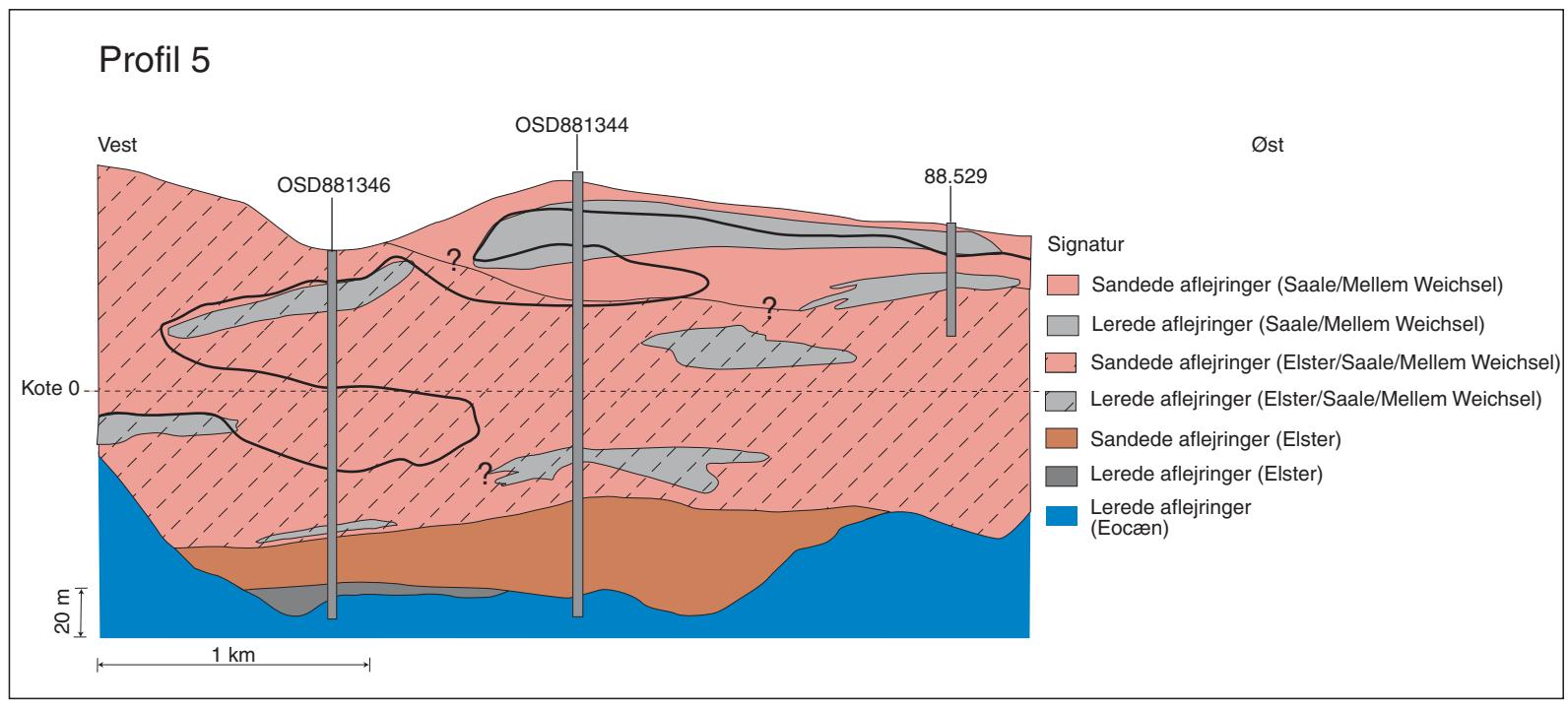

Geologisk profilsnit gennem HasselagerHørningJeksendalen (Grafik: Forfatterne) 


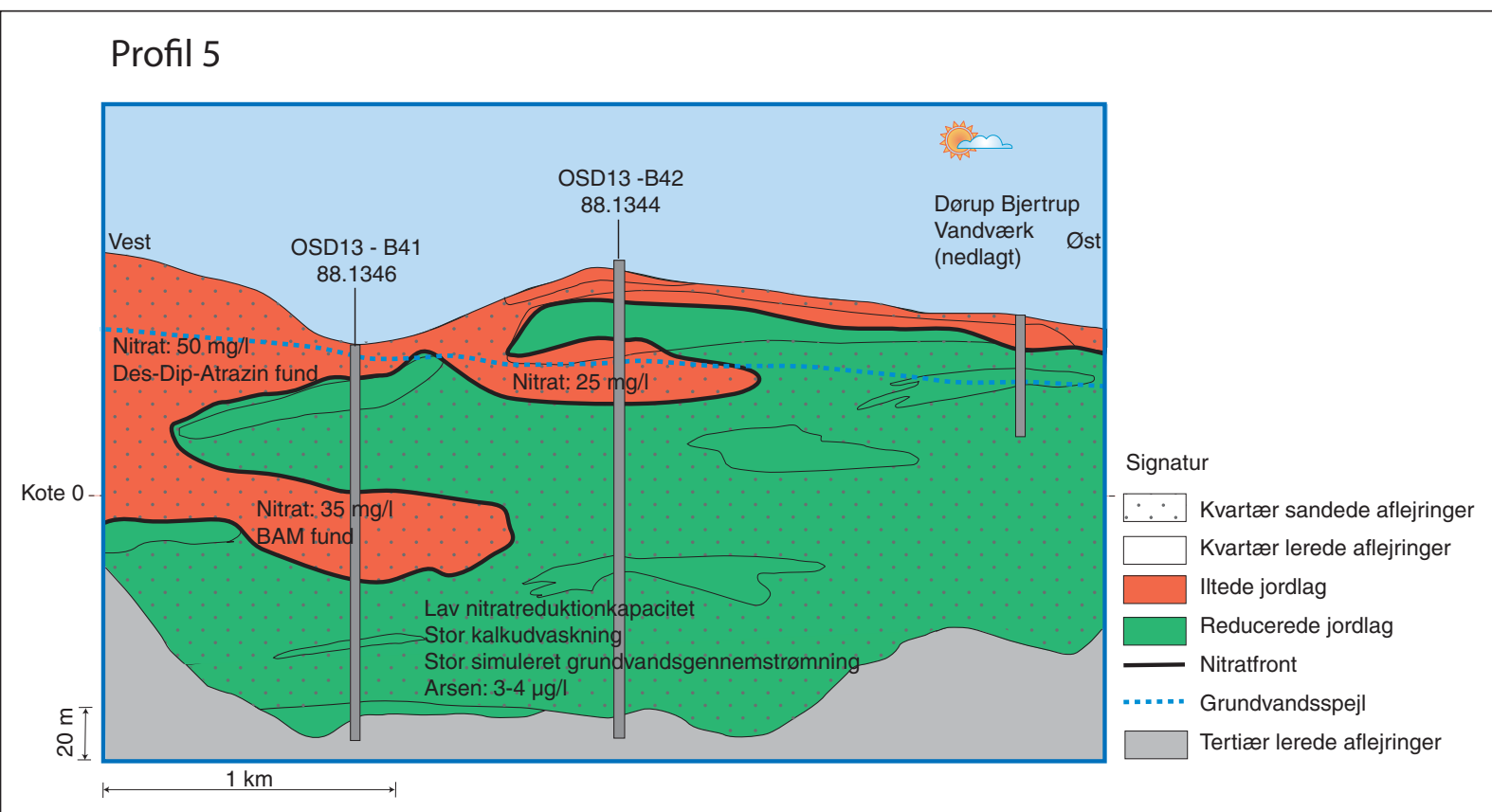

Skematisk

vand-og

geokemisk

profil af Has-

selager-Hør-

ning-Jeksen-

dalen. Grund-

vandsmagasin

med stor

nitratsårbar-

hed. (Grafik:

Forfatterne)

endal (se figuren på første side) ligger der et grundvandsmagasin med stor sårbarhed over for nitrat og andre miljøfremmede stoffer som for eksempel pesticider.

Det første indtryk var, at her var der fundet et stort sandet grundvandsmagasin med mulighed for indvinding af drikkevand $i$ fremtiden. De kemiske målinger og analyserne udført af SESAM fortæller dog samtidig, at grundvandsmagasinet er meget sårbart over for forurening fra overfladen. De vandkemiske målinger i de 2 undersøgelsesboringer viser, at nitrat og pesticider stedvist er trængt langt ned i grund- vandsmagasinet. Det kan ses på profilsnittet på figuren ovenfor ved de røde områder, som viser, hvor der er nitrat og pesticider tilstede i grundvandsmagasinet, mens de grønne områder indikerer, hvor grundvandet er nitratfrit.

De vandkemiske resultater understøttes af sedimentanalyserne, som viser en lille nitratreduktionskapacitet og en stor grad af kalkudvaskning i magasinet. De vandkemiske og sedimentkemiske resultater er igen understøttet af beregningerne fra grundvandsmodellen, som viser en stor vandgennemstrømning i magasinet.

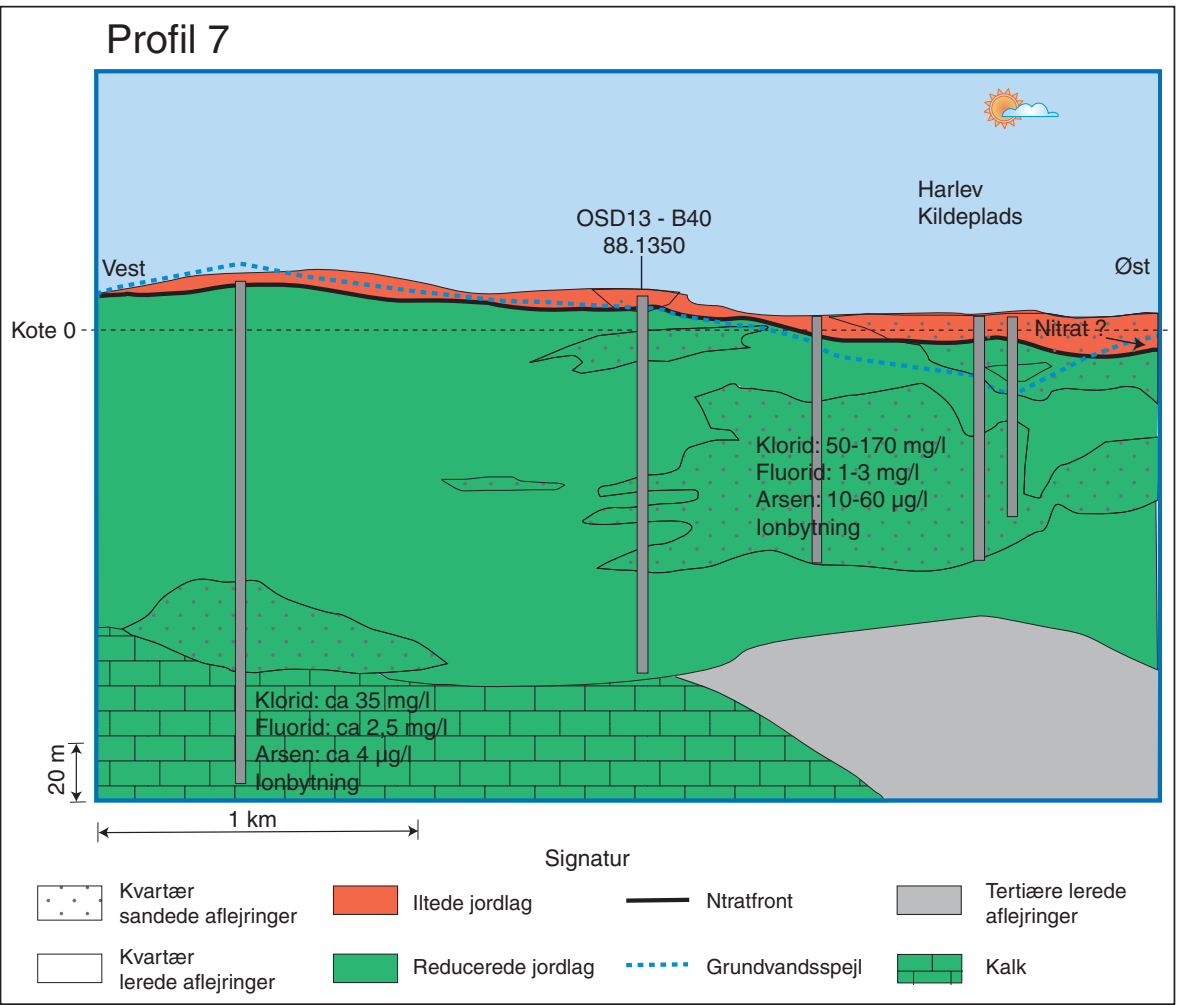

Skematisk vand-og geokemisk profil af Brabranddalen. Grundvandsmagasin med risiko for arsen i grundvandet. (Grafik: Forfatterne)
Magasin med stor risiko for arsenindhold I Brabranddalen (se figuren første side) ligger der et grundvandsmagasin, der har stor risiko for forurening med arsen og andre naturlige forekomne stoffer, som fluorid og klorid, i grundvandet.

Grundvandsforekomsterne i Brabranddalen har været kendt lige siden indvinding af grundvand til drikkevandsformål startede i Århus i 1902. Dalen er geologisk meget komplekst opbygget, og derfor er den kemiske tilstand af grundvandet også meget varierende.

Beskyttelsen af grundvandsmagasinerne i Brabranddalen mod menneskeskabt forurening er mange steder god på grund af tykke lerdæklag over grundvandsmagasinerne. På figuren nederst på denne side er dette illustreret ved, at de røde områder, hvor der kan være nitrat og pesticider i grundvandsmaga- 


\section{Eksempel på et hydrogeokemisk profil fra en undersøgelsesboring}

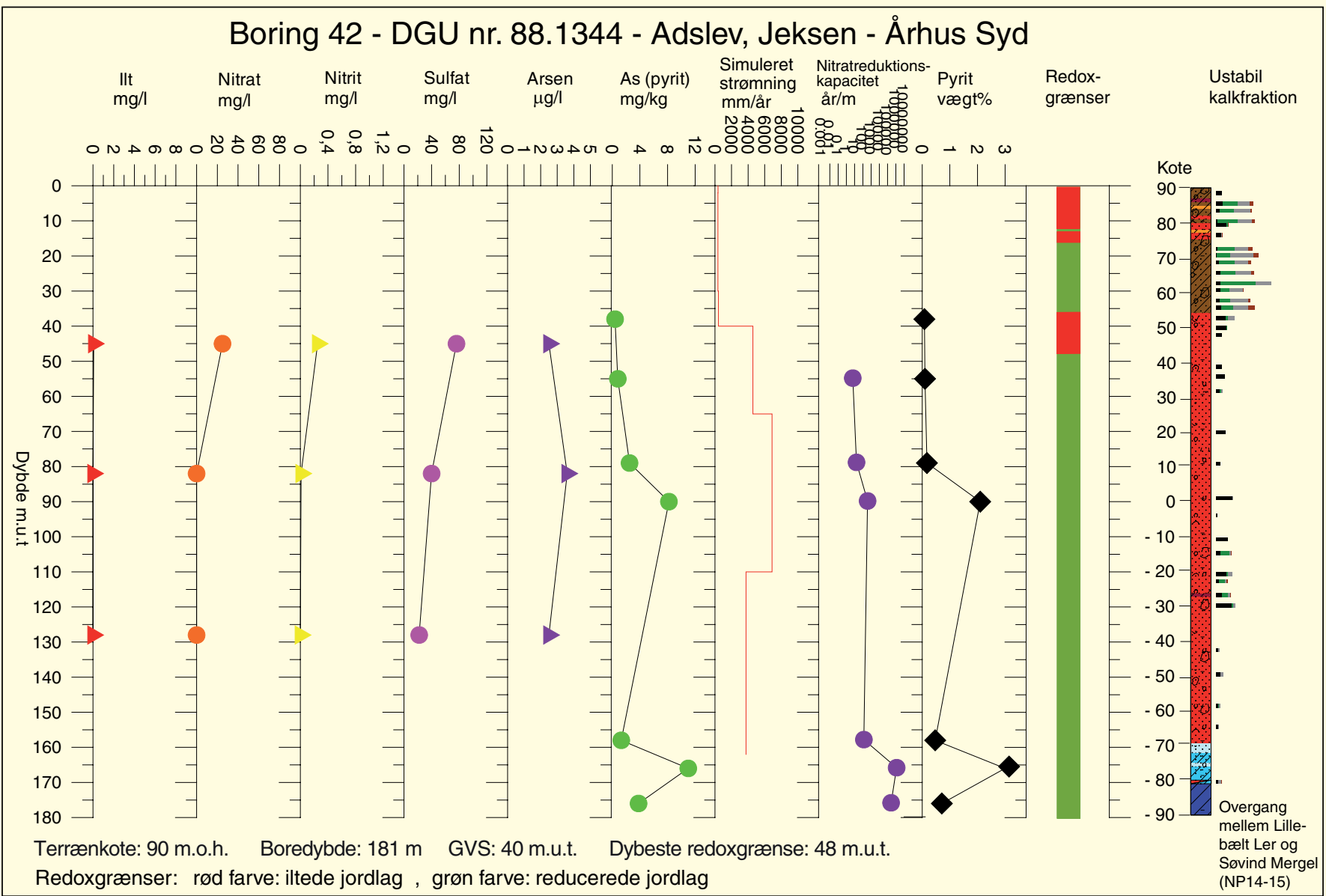

På figuren ovenfor er vist et eksempel på et hydrogeokemisk profil fra undersøgelsesboringen med DGU nr. 88.1344 fra den begravede Hasselager-Hørning-Jeksendal (se figuren på første side). (Grafik: Fofatterne)

\section{Geologi}

Boringen viser tilstedeværelsen af mægtige kvartære sandforekomster, op til omkring $120 \mathrm{~m}$, med indslag af moræne- og smeltevandsler. Boredybden er ca. $181 \mathrm{~m}$, grundvandsspejlet findes ca. $40 \mathrm{~m}$ under terræn, og terrænkoten er ca. $90 \mathrm{~m}$ over havet.

\section{Vandkemi}

De 3 filtre i boringen er alle placeret i det meget tykke grundvandsmagasin. Det øverste filter 3 (45-47 m under terræn) indeholder nitratholdigt og iltfrit grundvand fra den anoxiske zone (vandtype B). Filter 2 (82-84 m under terræn) og filter 1 (128-130 m under terræn) har nitratfrit, reduceret grundvand af vandtype $\mathrm{C}$.

\section{Sedimentkemi}

Farvebeskrivelserne af sedimentet fra boringen viser mange farveskift mellem rødlige og grålige farver. Det er derfor vurderet, at der er 5 redoxgrænser i boringen. Dette skyldes sandsynligvis en foretrukken strømning i den umættede zone og horisontal strømning i grundvandsmagasinet med kontakt til geologiske vinduer. Den dybeste redoxgrænse (48 $\mathrm{m}$ under terræn) indikerer, at nitratfronten er nået ca. 8 meter ned i grundvandsmagasinet. Det understøttes af fundet af nitrat i filter 3 (45-47 m under terræn).

Der er udført sedimentanalyser (pyrit og arsen i pyrit) på 7 prøver fra boringen. Det højeste indhold af arsen i sedimentet er fundet i det tertiære ler $(11 \mathrm{mg} / \mathrm{kg})$. I den oxiske zone af smeltevandssandet er pyritindholdet målt til 0,08 vægt $\%$. Pyritindholdet i den reducerede zone af smeltevandssandet er højere og varierer fra 0,1-2,1 vægt\%. Nitratreduktionskapaciteten er beregnet på baggrund af pyritanalyserne. Der er en del antagelser forbundet med beregningen. Bl.a. skal den beregnede nitratreduktionskapacitet betragtes som en minimumsværdi, da $\mathrm{Fe}(\mathrm{II})$ og TOC ikke er medtaget i beregningerne, pga. kontaminering fra boremudderet. Generelt er den beregnede nitratreduktionskapacitet meget lav i grundvandsmagasinet (ca. 10-400 år/m).

Grundvandsstrømningen (simuleret strømning med MIKE SHE), som ligger til grund for beregning af nitratreduktionskapaciteten, fremgår af figuren. Det ses, at der er simuleret en meget stor gennemstrømning fra 40-162 m under terræn (ca.3,7- 6,8 m/år) ved boringen. Simuleringen af vandgennemstrømningen stemmer overens med de mineralogiske undersøgelser fra SESAM, der viser en stor kalkudvaskning $\mathrm{i}$ smeltevandssandet i boringen. De mineralogiske resultater, angående kalkudvaskning, og beregningerne af den lave nitratreduktionskapacitet $\mathrm{i}$ det sandede grundvandsmagasin, indikerer dermed en stor risiko for nitrat i magasinet, til trods for, at der ikke er fundet nitrat $\mathrm{i}$ de 2 dybeste filtre.

sinet, kun findes i de øverste meter af jordlagene. Vandkemien i undersøgelsesboringen og i indvindingsboringerne ved Harlev Kildeplads (under Århus Kommunale Værker) viser, at grundvandet ikke er nitratholdigt. De vandkemiske resultater understøttes af de sedimentkemiske resultater, som viser en stor nitratreduktionskapacitet af lerdæk- lagene og en lille grad af kalkudvaskning i grundvandsmagasinet. Igen understøttes de vand- og sedimentkemiske resultater af beregningerne med grundvandsmodellen, som 
viser, at vandgennemstrømningen er meget mindre i Brabranddalen end for eksempel i Hasselager-Hørning-Jeksendalen (figuren første side).

Nogle steder i Brabranddalen er der høje koncentrationer af arsen, fluorid eller klorid i grundvandet. Dette skyldes ikke menneskeskabt forurening, men naturlige forhold $i$ grundvandsmagasinerne. Et højt indhold af arsen i grundvandet skyldes sandsynligvis, at der frigøres arsen fra sedimentet $i$ grundvandsmagasinet til det nitratfrie grundvand, og at arsen opkoncentreres i grundvandet, fordi vandgennemstrømningen er lille.

\section{Konklusion}

De petrografiske analyser fra SESAM er med stor succes blevet brugt til at opdele og korrelere den kvartære lagserie i undersøgelsesboringer i Århus Syd-området. Dateringen af de kvartære aflejringer har i stor grad bidraget til en øget forståelse af områdets geologiske opbygning. Kombina- tionen af sediment- og vandkemiske data samt petrografiske data har desuden vist sig at være et stærkt værktøj i vurderingen af grundvandsstrømningen og sårbarheden i de enkelte grundvandsmagasiner. Dog er det meget vigtig at få data så tidligt som muligt i kortlægningsforløbet, så resultaterne kan indgå i opstillingen af såvel de geologiske modeller som selve grundvandsmodellen.

\section{Referencer}

Kronborg C., Bender, H., Bjerre, R., Friborg, R., Jacobsen, H.O., Kristiansen, L., Rasmussen, P., Sørensen, P.R., og Larsen, G., 1990: Glacial Strategraphy of East and Central Jutland. Boreas, 19, 273-287.

Århus Amt, 2006. Redegørelse for grundvandsressourcerne i Århus Syd-området. Eds: Signe Weng Grønhøj, Birgitte Hansen, Ole Dyrsø Jensen, Birthe Eg Jordt, Stine Rasmussen, Richard Thomsen, (Under udarbejdelse).

\section{Kort nyt}

\section{Gamle Kalkgruber åbnet i Mønsted}

I 1939 styrtede dele af Mønsted Kalkgruber sammen. Siden har adgangsvejene til denne del af gruberne været spærret af sammenstyrtet materiale, og gruberne har derfor ligget uberørt hen. Nu har nye udgravninger afsløret, hvad der kan være en minegang til de gamle gruber. Dele af gruberne blev opmålt i 1933, men hvor meget, mere man nåede at grave inden sammenstyrtningen, vides ikke, siger lederen på stedet, Per Bugge Vegger.

Det er muligt, at de gamle gruber også åbnes for publikum til næste år.

\section{Sunken oceanbund dybt i Jordens indre} Dybt inde i Jorden, halvvejs mod Jordens kerne, har en gruppe seismologer fra University of California, Arizona State University og University of Minnesota fundet en foldet kæmpeplade, som engang var oceanbund. Pladen sank under Nordamerika for 50 millioner år siden og ligger nu $2.900 \mathrm{~km}$ nede i Jorden, hvor Jordens kerne møder kappen.

Opdagelsen har givet et betydeligt indblik i de processer, der driver bevægelsen af Jordens tektoniske plader. Jordens yderste lag, lithosfæren, brækker i store stive plader bestående af Jordens skorpe samt de ydre lag af kappen og føres ned i subduktionszoner, hvor en plade presses under en anden. Nyt plademateriale dannes ved spalter langs midten af oceanerne, hvor havbunden spredes fra hinanden. Det har længe været diskuteret om sådanne brudplader synker hele vejen ned til bunden af kappen eller forbliver øverst i kappen. "På dette ene sted ser vi ret stærke beviser for, at hele kappen omrøres", siger Garnero fra Arizona State University og fortsætter: "brudstykker som bevæger sig dybt ned i kappen, menes at drive konvektionen af materiale inde i Jorden. De har høj massetæthed og falder ind i kappen. Men de er forbundet til den ydre skal, som indeholder havbunden."Det er som en dug, der glider af et spisebord, tilføjer Garnero. "Hvis mere end halvdelen er gledet af bordet, falder dugen bare af og tager alt med sig".

Ved hjælp af seismiske data har seismologerne fundet ud af, at brudstykket af den tidligere oceanbund består af de samme mineraler som den omkringliggende kappe, men dens temperatur er ca. 700 grader koldere. Inde i kappen synker kolde klipper, mens skyer af varmt materiale stiger op mod overfladen, og denne langsomme omrøring menes at drive bevægelsen af Jordens tektoniske plader.

www.science.com/JT 